\title{
Refusing to Write Like Henry James: Women Reforming Realism in Fin-de-Siècle America
}

\section{Sarah Wadsworth}

\section{(2) OpenEdition \\ Journals}

Electronic version

URL: https://journals.openedition.org/ejas/9067

DOI: $10.4000 /$ ejas. 9067

ISSN: 1991-9336

Publisher

European Association for American Studies

\section{Electronic reference}

Sarah Wadsworth, "Refusing to Write Like Henry James: Women Reforming Realism in Fin-de-Siècle America", European journal of American studies [Online], 6-2 | 2011, document 7, Online since 04 April 2011, connection on 08 July 2021. URL: http://journals.openedition.org/ejas/9067 ; DOI: https:// doi.org/10.4000/ejas.9067

This text was automatically generated on 8 July 2021.

Creative Commons License 


\title{
Refusing to Write Like Henry James: Women Reforming Realism in Fin- de-Siècle America ${ }^{1}$
}

\author{
Sarah Wadsworth
}

1 In her novel Roger Hunt (1892) - a novel of near Jamesian nuance and irony-Celia Parker Woolley incorporates a scene in which a handful of characters engage in "psychological analysis" (35) of the eponymous antihero: a brilliant but unscrupulous egotist who has abandoned his alcoholic wife and persuaded a naïve, infatuated young woman to unite with him in a bigamous marriage. Following several pages of discussion of the scandalous incident and its perpetrator, Kitty Somers, Hunt's long-time friend, laments to her husband that Hunt's new bride "will be perfectly miserable!" (3). When her husband flippantly predicts, "No, she will be imperfectly miserable; but that's worse," Kitty exclaims "pettishly": “Oh, I wish you wouldn't try to talk like one of Henry James's novels" (36).

2 More than just a sly jab at a writerly technique that met with as much puzzlement as praise in the late nineteenth century, Woolley's allusion to James in this, her most Jamesian, novel begs for critical scrutiny. To begin, the remark suggests that even as James creatively responded to popular writers so, too, popular writers occasionally registered their responses to James's fiction in their own creative work. ${ }^{2}$ Revealing both a consciousness of-perhaps even a self-consciousness concerning-James's stature and style as well as a rejection of his rhetorical maneuvers, Kitty's remark in Roger Hunt signals a degree of discontent with the literary mode that would soon become canonized as high realism. By extension, the refusal to talk like Henry James serves as a point of entry into a vast body of work by American women writers of the late nineteenth century who chose to reject, revise, or, put differently, "reform" realism in order to fulfill their own literary and extra-literary ends.

3 Together with Woolley's earlier novels, Love and Theology (1887) and A Girl Graduate (1889), Roger Hunt was among the more than one thousand works of American fiction displayed in the library of the Woman's Building of the 1893 Chicago World's Fair. ${ }^{3}$ This 
library, amounting to over eight thousand volumes of writing by women, serves as my pool of data for this critical inquiry. Designed to showcase the literary achievements of women from across the country and around the world, the Woman's Building Library provides an unrivaled opportunity to contemplate fiction by American women en masse. Popular humorist Marietta Holley summed up the way many American women must have felt upon viewing this landmark collection of women's texts when she had the folksy protagonist of her novel Samantha at the World's Fair (1893) announce with evident pride: 'right here I see my own books; there they wuz a-standin' up jest as noble and pert as if they wuz to home in the what-not behind the parlor door, not afeelin' the least mite put out before princes, or zars" (255). While Samantha's homespun homage revels in the comforting familiarity of recognized texts, the literary historian today is struck, in contrast, by the preponderance of unfamiliar, unknown, unremembered texts.

4 For those interested in non-canonical women's writing of the late nineteenth century, the Woman's Building Library offers an embarrassment of riches. Owing to the fact that the collection grew largely through the grass-roots efforts of women involved in the international club movement, this library more closely reflects the "reality" of the overall corpus of women's writing than the tastes and ideals of a cultural elite selfselected to identify the "best" and most "important" works. This paper highlights three clusters of novels that depart from the canonical realist text-what I will call the domestic reform novel, the regional reform novel, and the historical reform novel. By considering both form and reform in these ubiquitous nineteenth-century novels, this essay explores the assumptions and aims of some of those late nineteenth-century writers who, like Celia Parker Woolley, preferred not to write like Henry James.

5 Despite their obscurity as literary figures, a surprising number of the novelists in the Woman's Building Library would be easily recognizable to anyone schooled in the annals of U.S. women's history. In fact, many prominent women who were active in reform movements, especially women's rights, and in professional activities beyond the domestic sphere wrote fiction in conjunction with their professional and reform activities, often producing novels in tandem with nonfiction works. According to the view of these novelist-reformers, fiction-like women's clubs, newspapers, magazines, tracts, courses of study, petitions, and church auxiliaries-constituted a potentially effective medium of social reform. And, typically, their fiction reflects precisely the social problems and concerns that they addressed through other avenues, such as journalistic writing, public speaking, club activities, community service, education, and reform organizations. The novels they published descend from the large class of fiction Jane Tompkins illuminates in Sensational Designs-fiction that "articulat[es] and propos[es] solutions for the problems that shape a particular historical moment" (xi). In the Preface to her novel Rebecca; or, A Woman's Secret (1867), novelist-reformer Caroline Corbin sums up this approach, stating, "It is not strictly as a work of art that this book appeals to public favor and criticism. It has not been written for immortality, but to serve, if it may, a single purpose to the present day and generation" (5). In using fiction to address complex social problems, women like Corbin participated in a wideranging and influential literary reform movement in nineteenth-century America: a movement aimed at re-forming literature as well as enlisting literature in the cause of social reform. As summed up by a representative of the Woman's Christian Temperance 
Union, "fiction is too powerful a weapon to be left in careless hands" (quoted in Parker 141).

6 The existence of so many reform novels, and their inclusion in the Woman's Building Library, is a testament to the power that many nineteenth-century writers ascribed to fiction as an agent of social change. This was a tradition of nineteenth-century women writers and reformers who identified the home as their locus of influence and sought to bring the highest ideals of the domestic sphere to bear on the world at large. In many cases, novelist-reformers of the late nineteenth century upheld this time-honored belief in the sanctity of women's domestic role while actively engaging in timely reform efforts that targeted a wide range of social ills. More than a few of them sought to expand women's role beyond the confines of the home, however, into such traditionally male professional havens as medicine and law. Moreover, some went beyond the reform of existing social institutions to advocate more radical solutions. Often their aims coincided with those of earlier novelist-reformers such as Lydia Maria Child and Harriet Beecher Stowe; however, the novelist-reformers of the fin de siècle were decidedly post-sentimental in ideology and technique.

7 Many critics over the years have faulted reform fiction, "problem novels," and protest literature for their privileging of didacticism over aesthetics. Critics of the late nineteenth century, however, often located in the best fiction of this type a synthesis of the didactic and the aesthetic. Indeed, for many readers, morality was an indispensable component of art. ${ }^{4}$ Celia Parker Woolley addressed precisely this debate in an 1893 letter to the editor of the Dial:

Is our coming literature to be chiefly a medium of instruction, of moral impulse and inspiration, or of mere æsthetic or intellectual enjoyment? Is it to be dominated most by the living instincts of those who write and those who read, or by the socalled art-spirit? What is the true proportion between this art-spirit and a more didactic purpose? In a word, how real and strong and vital are we willing our literature should become? "The East and the West, Once More" 216; quoted in Schweninger 49-50)

Woolley's use of the word "real" here clearly establishes the terms of the debate. In this piece, Woolley criticizes fiction that is merely "the mouthpiece of a great idea, unveiling some social wrong or abuse, stimulating men to clearer thinking and better living" but lacking in "literary flavor" and argues for a proper balance between the "art-spirit" and "ethical purpose." She defends "[t]he literary consciousness of the West, as represented in a writer like [Hamlin] Garland." According to Woolley, this "literary consciousness ... is profoundly stirred by those new ideals which demand a larger thought and life-content in literature, which would make it the servant of humanity's most pressing needs, using it to stimulate thought, elevate social conditions and standards, sweeten and ennoble life all round." As Woolley explains, "Mr. Garland belongs to that class of writers, of which Helen Gardiner is a still more marked example, who care more about life than about theories of the art which seeks to express and represent life: a choice wisely made from both the moralist's and artist's point of view" (217).

9 In crafting their fiction to fill the role of "servant of humanity's most pressing needs," many novelist-reformers joined Woolley in holding their fiction to high ethical as well as artistic standards and aspiring to greater humanitarian heights than they believed the "art-spirit" alone could attain. ${ }^{5}$ Strictly belletristic or "aesthetic" literature was not, for them, a loftier form, but, rather, a vitiated mode, diminished by its detachment 
from the troubled conditions and immediate needs of contemporary society. For Woolley and the other writers discussed here, intellectualized aestheticism saps fiction of its engagement with real social issues while moralism (insofar as it avoids dogmatism and partisanship) can infuse it with life and bring together "those who write and those who read" in a community of benevolence. And if such fiction was not yet universally praised, its canonization was only a matter of time, predicted some. According to a section titled "Woman in Literature" in the 1890 volume Woman; Her Character, Culture, and Calling, "the time will surely come when combined benevolent and aesthetic purposes will be considered the test of highest merit, and when that day comes, the number of women esteemed among the worthies of literature will be proportionately much greater than now" (Bourinot and Austin 107).

10 Along with Roger Hunt, Woolley's novel A Girl Graduate typifies what I referred to earlier as the domestic reform novel. Shortly before this novel's publication, Woolley summed up its dominant theme as the "social life and aspirations of a beautiful young girl, daughter of a working man, who has been educated beyond the sphere in which she was born." In this novel Woolley, a "literary activist" of the first rank, ${ }^{7}$ tells the story of Maggie Dean, a recent high school graduate in the Midwestern town of Litchfield. Although a star orator, smart and well-liked, Maggie finds that after finishing school she has no direction, no pressing plans. Instead, "[a] hundred contradictory plans and ambitions filled her mind." Moreover, "[u]nlike most of her mates, Maggie was unwilling to spend her days in a round of empty cares. She could not be always arranging her room or making over her dresses" (240).

11 In fact, the novel is not so much about formal education in itself; instead it reveals the consequences of education in day-to-day life, the opportunities it opens up, and the avenues that remain closed as a result of inadequate access to higher education. Woolley shows how Maggie's real education begins only after graduation when she confronts and overcomes the limited expectations and opportunities granted her. In this particular-the novel's studied analysis of the causes and consequences of the limitations imposed on a young woman of imagination, intelligence, and sensitivityWoolley's theme is not substantially different from that of James in such novels as The Europeans and The Portrait of a Lady. But in A Girl Graduate Woolley is more interested in exploring practical solutions than in exposing ambiguities and anatomizing conflicted psyches.

12 In the process of pursuing her post-high-school education, Woolley's heroine disappoints an earnest and honorable suitor, walks a fine line between friendship and flirtation with a less serious and less honorable young man, and rebuffs the undesired advances of two much older men-a married minister, old enough to be her father, whose attentions to her are altogether repellant, and an even older judge who hopes that his high status in the town will reconcile her to a "mercenary marriage" (299). Rather than acquiescing in a marriage of convenience, Maggie spends "hours in profound study," determined to "work ... study ... improve herself in a hundred ways . . be discreet and dignified . . [and] learn to say sharp things to people" (240-41). ${ }^{8}$ Following the example of her older sister, Maggie overcomes her "girlish dread of being considered 'literary' and 'strong-minded,' terms of opprobrious meaning in a community like Litchfield" (257) and eventually befriends Miss Graham, a somewhat Bohemian "strong-minded" and "independent spinster" who presides over a liberal reading and discussion group known as an Emerson Club. (As the narrator informs us- 
perhaps with a veiled allusion to her own project in the novel Love and Theology -"through the insidious paths of literature [Miss Graham] tried to lead [the young people's] minds away from a decrepit theology" [196].) Maggie encounters many stumbling blocks over the course of this bildungsroman-including the grave illness of her mother, a crippling on-the-job injury sustained by her father, a social humiliation, and employment discrimination, as well as the sexual harassment alluded to earlier; nevertheless, she gains considerable independence, maturity, and self-respect along the way. In addition, by continually stressing "usefulness" and service to others, Woolley reinforces her own approach to the writing of fiction while suggesting that women who seek education and employment outside marriage are not shirking their duty but rather expanding upon and fulfilling it.

13 A close cousin of the domestic reform novel, Winnie Louise Taylor's His Broken Sword (1889) exemplifies the regionalist novel adapted to reformist ends. Set in Milwaukee, Wisconsin, His Broken Sword deliberately establishes a sense of location that is both geographically authentic and thematically significant. In this novel, Taylor conceives of the Upper Midwest as a place where the heroine, Katherine, can combine the best influences of a Southern mother, who strives to redeem her participation in slavery through philanthropical support of African Americans, and a Northern father, the product of traditional New England education and culture. With this synthesis of cultural influences creating fertile ground upon which the heroine may flourish, Taylor unexpectedly introduces the theme of prison reform, which becomes the focus of the novel. The conflict centers on Katherine's engagement and subsequent marriage to Robert Allston, a man who inadvertently kills another man while defending her honor. Through Robert's incarceration, the novel explores a series of questions leveled at the criminal justice system: "What must be the moral effect of all this forcing, cramping, deadening process? What kind of men were likely to be turned out from this crushing, relentless, indiscriminating governmental machine, where the good and the bad, the weak and the depraved, the young and the old, were massed in together and levelled over by a resistless plane? What chance for the bruised reed here?" (262-63).

In the 1893 edition of His Broken Sword a new preface by Edward Everett Hale, to whom the book was dedicated, explains that Taylor "did not write the book because she wanted to write a story" but rather "because she wanted thoughtful people in America to remember the prisoner in his prison." Emphasizing rational inquiry, compassion, and conscience, rather than sentimentality or literary virtuosity, Hale continues:

Miss Taylor would tell us that she has written this book, not for the purpose of winning repute as an author, not for the purpose of making us cry as we read of the long-wrought suffering of her hero; but to interest us, as she has been interested, in the lives of those who are within the four walls. And I think she means that the book shall ask us the question whether we do personally know the lives of prisoners, the lives of prisoners' families, the method of administration of the prison system, as we ought to know these things. For one, I shall be surprised if any person can read this book through without a quickened conscience in these affairs. (vii-viii)

15 For Hale, and for other advocates of the reform novel, stimulating interest, activating conscience, and spurring readers to action is more important than proffering entertainment, promoting aesthetics, inflaming emotions, or cultivating the imagination. Equally important, the author does not write fiction seeking literary 
laurels to advance her own reputation; rather, this kind of reformed realism is a selfless pursuit undertaken in the interests of protecting the powerless.

For the most part, contemporary reviewers concurred with Hale in his high appraisal of the novel's ends and means. Although one reviewer expressed the opinion that His Broken Sword "is a strong story not dependent for its interest on the thread of earnest purpose which runs through it" ("Fiction" 186), the Wisconsin Journal of Education declared that the novel "was written with a purpose by one who in philanthropic work has had long acquaintances with prison life .... The good in the midst of evil even in criminals, the burden of a debased nature dragging men down who are further crushed by the harsh treatment of their fellows - all this and more as an effective plea for a more kindly, considerate, helpful and wise treatment of those who are classed as criminals" ("Our Book Table" 460). A reviewer for The Dial similarly focused on the novel's "underlying motive," noting that "[i]t is really an argument for prison reform, and one made all the more convincing to judicious minds by its rejection of all the methods of sensationalism ... The plea is silently and unobtrusively enforced" (Payne 66-67). Just as Hale, in his preface, implicitly praised the novel for its lack of sentimentality, these reviews do not fault His Broken Sword for its undisguised moralism but rather admire it for its unsentimental, non-sensational, realistic, and judicious scrutiny of the problem of prison reform.

17 In contrast to canonical regionalism as represented by such authors as Sarah Orne Jewett, Kate Chopin, Mary Wilkins Freeman, and Rose Terry Cooke, which often evokes a nostalgic sense of a traditional rural past, regional reform novels tend to depict present conditions while simultaneously looking forward to the future. Similarly, historical reform novels bend generic conventions by looking ahead to the future even as they attempt to reconstruct a sense of a region's communal past. In the preface to her novel The Heroine of '49: A Story of the Pacific Coast (1891), novelist and medical doctor Mary P. Sawtelle evinces this dual tendency to look backwards and forwards simultaneously, remarking that she believes "full well that a time will come when a people enjoying the magnificence and marvelous wealth of these Pacific States will look back with hearts filled with gratitude to the people who laid the foundation for it all, made sacrifices and endured privations that would be difficult for any historian, however accurate or gifted, to portray, and any account of those days, however imperfect, will be held sacred by them forever" (8). In this novel, in which Dickensian, allegorically named villains mix with real-life historical figures, Sawtelle blends history, satire, romance, and politics in a peculiar hybrid form.

18 The Heroine of ' 49 depicts the lives of the first white settlers of Oregon in order to expose the gender and racial inequity that persists in the present so that readers might be persuaded to put into place reforms for the future. In the novel's preface, Sawtelle directly states her goal of disabusing readers of the commonly held belief that girls mature faster than boys, a false perception that was used to justify early marriages involving child brides. Over the course of the novel, however, Sawtelle's scope broadens substantially, taking in the injustices of the Indian wars, the dispossession of tribal lands, the forcing of Indians onto reservations, domestic violence, divorce, land laws that encouraged men to marry simply so that they could increase their acreage, and laws that placed children of divorce with abusive fathers while depriving their mothers of children, property, income, and social standing. ${ }^{9}$ In addition to chastising lawmakers angrily for failing to protect women and children, Sawtelle directs 
considerable invective at the U.S. government for not honoring its treaties with Indians, not compensating Indians for their land, and not paying American citizens who fought in the Indian wars. Thus, she argues, the government wronged both sidesIndians and settlers-in its greed for new land. The result, according to one reviewer, was a book that, while "sufficiently striking" and "real," is "not pleasant reading" (“Recent Fiction" 333).

19 Nancy Glazener has observed that on some occasions "reform fiction was . . . assimilated to the project of high realism" (43); yet I do not see these writers as assimilating their reformist goals to this "'establishment' form" (11). Nor do I see these women writers rejecting realism as "a coarse male habit" from which they retreated to "the old path of ideality and hopefulness and a glorious model of what true marriage should be or what the true woman was," as Alfred Habegger suggests of certain nineteenth-century women writers who rejected realism (37). Instead, I see the blend of realism, regionalism, history, and domesticity in their fiction as a search for form motivated by the desire to reform realism by adapting familiar models to current social needs. Their faith in the capacity of fiction not just to reflect but to create reality underlies the observation in Lillie Devereux Blake's 1874 novel Fettered for Life that "Just so long as all our literature is pervaded with the thought that women are inferior, so long will our sex be held in a low estimate" (254). As Blake and many other nineteenthcentury women writers would have it, reforming the novel and hence reforming literature more broadly was a vital step to reforming society itself.

\section{BIBLIOGRAPHY}

Blake, Lillie Devereux. Fettered for Life; or, Lord and Master. A Story of to-Day. 1874. Ed. Grace Farrell. New York: The Feminist Press at the City University of New York, 1996.

Bourinot, John George and Benjamin Fish Austin, eds. Woman; Her Character, Culture, and Calling. Brantford, Ont., Canada: The Book and Bible House, 1890.

Corbin, Caroline Fairfield. Rebecca; or, A Woman's Secret. Chicago: Central Publishing House, 1867.

"Fiction." The Literary World: A Monthly Review of Current Literature 25 (June 16, 1894): 185-86. American Periodicals Series Online. Retrieved November 24, 2010.

Glazener, Nancy. Reading for Realism: The History of a U.S. Literary Institution, 1850-1910. Durham, N.C.: Duke UP, 1997.

Habegger, Alfred. Gender, Fantasy, and Realism in American Literature. New York: Columbia University Press, 1982.

Hale, Edward Everett. Introduction. His Broken Sword by Winnie Louise Taylor. $2^{\text {nd }}$ Ed. Cambridge and Chicago: Stone and Kimball, 1893.

Holley, Marietta. Samantha at the World's Fair. New York: Funk \& Wagnalls, 1893.

“Our Book Table." Wisconsin Journal of Education 18 (1888): 457-61. GoogleBooks. Retrieved March 18,2008 . 
Parker, Alison M. “'Hearts Uplifted and Minds Refreshed': The Woman's Christian Temperance Union and the Production of Pure Culture in the United States, 1880-1930." Journal of Women's History 11 (Summer 1999): 135-58.

Payne, William Morton. "Recent Fiction." The Dial; A Semi-monthly Journal of Literary Criticism, Discussion, and Information 9, no. 99 (1888): 65-69. American Periodicals Series Online. Retrieved November 26, 2010.

"Recent Fiction." Overland Monthly and Out West Magazine 19 (March 1892): 330-33. American Periodicals Series Online. Retrieved March 18, 2008.

Sawtelle, Mary P. The Heroine of '49: A Story of the Pacific Coast. n.p., 1891.

Schweninger, Lee. The Writings of Celia Parker Woolley (1848-1918): Literary Activist. Lewiston, NY.: Edwin Mellon Press, 1998.

Taylor, Winnie Louise, His Broken Sword. Chicago: A. C. McClurg and Co., 1889.

Tompkins, Jane. Sensational Designs: The Cultural Work of American Fiction, 1790-1860. New York: Oxford UP, 1986.

Woolley, Celia Parker. "The East and the West, Once More." Letter to the Editor. The Dial; A Semimonthly Journal of Literary Criticism, Discussion, and Information 15, no. 176 (1893): 216-17. American Periodicals Series Online. Retrieved November 26, 2010.

---. A Girl Graduate. Boston and New York: Houghton Mifflin, 1889.

---. Love and Theology. Boston: Ticknor and Co., 1887.

---. Roger Hunt. Boston and New York: Houghton Mifflin, 1892.

\section{NOTES}

1. I would like to thank Donatella Izzo and Greg Zacharias for organizing a fruitful workshop on "realism and its discontents" at the 2008 conference of the EAAS (Oslo). In addition, I am grateful to Wayne A. Wiegand, with whom I have collaborated on a history and analysis of the Woman's Building Library of the 1893 Chicago World's Fair ("Right Here I See My Own Books": A Cultural History of the Women's Library at the World's Columbian Exposition, forthcoming, 2012, from the University of Massachusetts Press).

2. For discussions of James's revisions of popular literature, see Alfred Habegger, Henry James and the "Woman Business" (Cambridge and New York: Cambridge University Press, 1989); Adeline R. Tintner, The Pop World of Henry James: From Fairy Tales to Science Fiction (Ann Arbor, Mich.: UMI Research Press, 1989); and Chapter 5 of my own In the Company of Books: Literature and Its "Classes" in Nineteenth-Century America (Amherst and Boston: University of Massachusetts Press, 2006).

3. For an overview of, as well as specialized articles on, the Woman's Building Library, see Libraries and Culture: A Journal of Library History 41.1 (Winter 2006).

4. See Lee Schweninger, The Writings of Celia Parker Woolley, for a detailed study of how Woolley "turned to fiction in pursuit of social and political change" (146) and "use[d] the novel as a vehicle to analyze and explore social concerns such as the place of religion and the status of women in nineteenth-century America" (75).

5. The Woman's Christian Temperance Union (many of whose publications appeared in the Woman's Building Library) attempted to implement this fusion of literary and moral aims on a large, institutional scale through its Department for the Promotion of Purity in Literature and Art. As Alison M. Parker explains, “The Department for the Promotion of Purity in Literature and 
Art defined a cultural hierarchy that prioritized morality as a crucial component of aesthetics, and then created those cultural products it deemed superior according to this standard of purity." According to this view, "that "which was not morally sound could not be aesthetically pleasing."' See Parker 137-38.

6. Coldwater Republican, 19 Feb. 1889, 5; quoted in Schweninger 27.

7. The phrase is Schweninger's. In his full-length study of Woolley, Schweninger characterizes his subject as "exemplary of her historical moment" (4)-a woman who "typified her class, sex, and generation in several ways" (5), including her active participation in the club movementeven as she "stands out as somewhat unique among her contemporaries" (23) in extending her commitment to equal rights and opportunities to African Americans and other oppressed groups. 8. One wonders if learning to "say sharp things to people" (an ironic indication that Maggie does not yet truly understand the value of reading, work, and self-improvement) is what Woolley meant by "talk[ing] like one of Henry James's novels."

9. On the land laws, one reviewer explained: "These were framed with extreme liberality, giving every married man a claim to six hundred and forty acres, or a section one mile square; but requiring one half of the grant to be entered in his wife's name. No single man could hold more than three hundred and twenty acres. The result of this provision, which was framed with the object of protecting women, was in some cases most disastrous. Every man that had not a wife already set about finding one immediately. Women were scarce, and children of only fourteen, sometimes even eleven, years were married to men twice their own age." See "Recent Fiction," 333.

\section{INDEX}

Keywords: A Girl Graduate, A Woman's Secret, Chicago World's Fair (1893), divorce, domestic reform novel, domestic violence, Fettered for Life; or, His Broken Sword, historical reform novel, Indian rights, land reform, Lord and Master, Love and Theology, marriage, prison reform, realism, Rebecca; or, reform movements, regional reform novel, regionalism, Roger Hunt, The Heroine of '49, women's club movement, women's education, World's Columbian Exposition 